International Journal of
Agriculture
(IJA)

\title{
ENHANCING ORGANISATIONAL PERFORMANCE IN THE DAIRY INDUSTRY: SUPPLY CHAIN MANAGEMENT APPROACH
}

Charles Maina, Prof, Benard K. Njehia and Dr Bett Kiprotich Eric

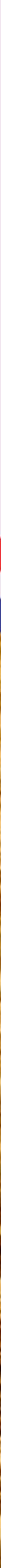




\title{
ENHANCING ORGANISATIONAL PERFORMANCE IN THE DAIRY INDUSTRY: SUPPLY CHAIN MANAGEMENT APPROACH
}

\author{
${ }^{1 *}$ Charles Maina \\ Post Graduate Student: Department of Agricultural Economics: Kenyatta University \\ wainainacmus@yahoo.com \\ ${ }^{2}$ Prof, Benard K. Njehia \\ Lecturer: Department of Agricultural Economics: Kenyatta University \\ ${ }^{3}$ Dr Bett Kiprotich Eric \\ Lecturer: Department of Agricultural Economics: Kenyatta University
}

\begin{abstract}
Purpose: The purpose of this paper is to explore the effects of supply chain management practices on the organizational performance underpinned on resource-based view theory (RBV).

Methodology: The study adopts descriptive and explanatory research design with purposive sampling and quantitative methods to collect primary data through crossed ended questionnaires from 109 dairy co-operatives in Kenya. Data collected was organized and cleaned using both excel and statistical package for social scientist (SPSS). Additionally, partial least squares structural equation modelling (PLS-SEM) techniques were used to analyze data in SmartPLS version 3.2 software, and the results for both descriptive and inferential were presented in tables.

Results: The result revealed that SCMPs has a positive and significant impact on Market performance $(\beta=0.558)$, operational performance $(\beta=0.371)$ and customer satisfaction $(\beta=0.543)$. These results reveal that SCM practices are associated with high levels of organizational performance. Thus, SCM practices explain and predict the organizational performance of the dairy industry in Kenya.

Unique contribution to theory, practice and policy: The study provides evidence of the building blocks of supply chain management practices and a framework of their implementation for performance improvement to the managers in the dairy industry. Theoretically, the study contributes to the development and advancement of the theory of supply chain management (SCM) as well as validation of the Resource-based View (RBV). Policy-wise, the study provides directions for coming up with policies geared towards performance improvements in the dairy industry.
\end{abstract}

Key Words: Supply Chain Management Practices, Organizational Performance, Structural Equation Modelling 
International Journal of Agriculture

ISSN 2520-4629X (Online)

Vol.5, Issue 1, No.2. pp 25 - 38, 2020

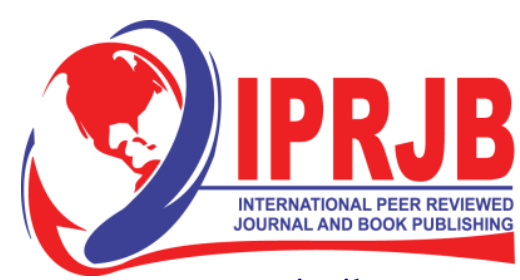

www.iprjb.org

\subsection{INTRODUCTION}

The concept of supply chain management (SCM) has become a popular topic in both academic research and business practices. SCM entails seamless integration of value-creating activities across organizational boundaries while minimizing system-wide costs in order to build a high performing business model cohesively. Therefore, the fundamental goal of SCM is to integrate and manage the sourcing, flow, and control of materials through a total systems perspective across multiple functions and multiple tiers of suppliers (Susanty, Bakhtiar, Purwaningsih, \& Dewanti, 2018). However, to achieve seamless integration of value-creating activities across the supply chain (SC) require firms to implement a set of SCM practices.

According to Sukati, Hamid, Baharun, \& Yusoff, (2012), a supply chain (SC) includes suppliers, manufacturer, suppliers, transporters, warehouses, retailers and the ultimate consumer of goods and services. Thus, SCM practices include a set of approaches implemented by a firm to integrate suppliers, manufacturers, distributors and customers effectively to improve the longterm performance of the individual organization and that of SC as a whole in a cohesive manner (Gorane \& Kant, 2017). The dual effects of SCM practices on the performance of an individual organization and that of the entire supply chain explain the strategic nature of SCM (Sundram, Ibrahim, \& Govindaraju, 2011).

The literature cites that the short-term goal of SCM is to reduce inventory and cycle time to increase productivity while the long-term goals are to increase market share and profitability (A. Kumar \& Kushwaha, 2018). SCM enhances operational performance through costs reductions, improved delivery time, reduce inventory and lead time (Harnowo, 2015). Additionally, SCM leads to high customer satisfaction which influences the repurchase behaviour of customers and hence leading to improved profitability (Kant, 2017). Moreover, long-term partnership relations with suppliers and customers helps to improve the flexibility of the SC by forming mutual understanding among the members. Thus, SCM practices play an important role in generating a competitive advantage and enhancing organisational performance.

The dairy supply chain starts with milk production by the farmer, transportation to plant, milk processing, packaging and distribution to retailers and finally to consumer (Mor, Singh, \& Bhardwaj, 2018). Irrespective of the ownership structure, dairy processing firms coordinate vital SC activities such as milk sourcing and procuring milk from farmers, collection and bulking, processing, product development and brand manufacturing, and post-processing distribution and delivery services in a business-to-business (B2B) relation with customers (Abdulsamad \& Gereffi, 2016). The activities within and across the echelon in the dairy supply chain require effective integration and coordination to ensure efficient allocation of resources among the chain partners. Therefore, dairy processors must consider the infusion of SCM practices to improve not only their performance but also that of their chain partners through collaborations and integration of supply chain activities.

\subsection{Statement of the Problem}

The dairy processing firms in Kenya are facing stiff competition from the informal milk channels, which controls $70 \%$ of the marketed milk. Moreover, the milk industry is experiencing fluctuations in milk supply and quality of raw milk supply. Consequently, the milk processing firms report low capacity utilization estimated at (40\%-50\%) of the dairy installed processing 
capacity (MoALF, 2017). Inadequate milk supplies disrupt the operations of the processing plants, thereby reducing efficiency and create cycles of milk gluts, followed by shortages (Mbugua et al., 2012). Further, low quality affects shelf life and reduces the volume of milk available for processing compromising the overall profitability of the milk processing firms (Njiru, 2018).

The current situation has eroded the competitiveness of the dairy processing firms threatening their long term sustainability and survival. Therefore, dairy firms must seek new ways of achieving competitive advantage and enhancing performance in order to survive and sustain in an increasingly competitive global marketplace. Thus, dairy firms need to recognize the importance of SCM practices to improve not only their performance but also that of their supply chain partners through join collaborations and coordination (Mutuerandu \& Iravo, 2014).

SCM can play a central role in generating a competitive advantage and improving organizational. Through SCM practices dairy firms can minimize their system-wide costs and also provide maximum value to their customers (R. Kumar, 2016). However, the literature is scarce on the influence of SCMPs on organizational performance, particularly in the Kenyan dairy supply chain context. Thus, the central goal of the current study is to uncover the effects of SCMPs on the organizational performance of the dairy industry in Kenya.

\subsection{Objectives of the study}

The study sought to explore the relationship between SCM practices and organizational performance of the dairy industry in Kenya. The specific objective of the study are:

i. To explore the effects of SCM practices on the operational performance of the dairy industry in Kenya

ii. To explore the effects of SCM practices on the market performance of the dairy industry in Kenya

iii. To explore the effects of SCM practices on the customer satisfaction of the dairy industry in Kenya

\subsection{LITERATURE REVIEW}

\subsection{Theoretical Framework}

The current study is hinged on the resourced based view (RBV) theory espoused by Edith Penrose in 1959. The RBV theory stipulates that the fundamental sources and drivers of competitive advantage and superior performance are mainly associated with the strategic resources owned and controlled by a to the firm (Rose, Abdullah, \& Ismad, 2010). According to Kamasak (2013), firm resources include all assets such as capabilities, organizational processes, firm attributes, information, and knowledge controlled by a firm that enables the firm to conceive and implement strategies that improve its efficiency and effectiveness. Accordingly, these resources must be valuable, rare, an inimitable and unsubstitutable to have the potential to generate superior performance (Saqib \& Rashid, 2013). However, it requires a distinctive combination of these resources and capabilities to register meaningful gains in performance. Therefore, the RBV emphasizes strategic choice, charging the firm's management with the important tasks of identifying, developing and deploying key resources to maximize returns. 
RBV theory provides a framework to analyze the relative degree of relationship between the internal organizational resources, competitive advantage and performance. Thus, building on the assumptions of RBV, the current study conceptualizes SCM practices as strategic resources use them to explain and predict the organizational performance of the dairy enterprises in Kenya. Extant literature shows that organizations implementing SCM achieve improved performance in terms of cost savings, increased revenues and the reduction of defects in products (R. Kumar, 2016). Additionally, SCM improves market responsiveness, reduce logistic cost, add economic value and the optimum utilization of capital cost (Muhammad, Akhter, \& Kafayat Ullah, 2014). As such the following alternative hypotheses are postulated

Hal: The level of operational performance varies with the level of SCMPS

Ha2: The level of market performance varies with the level of SCMPs

Ha3: The level of customer satisfaction varies with the level of SCMPs

The link between SCM practices and organizational performance (operational, market performance and customer satisfaction) is examined using the conceptual framework shown in figure 1.

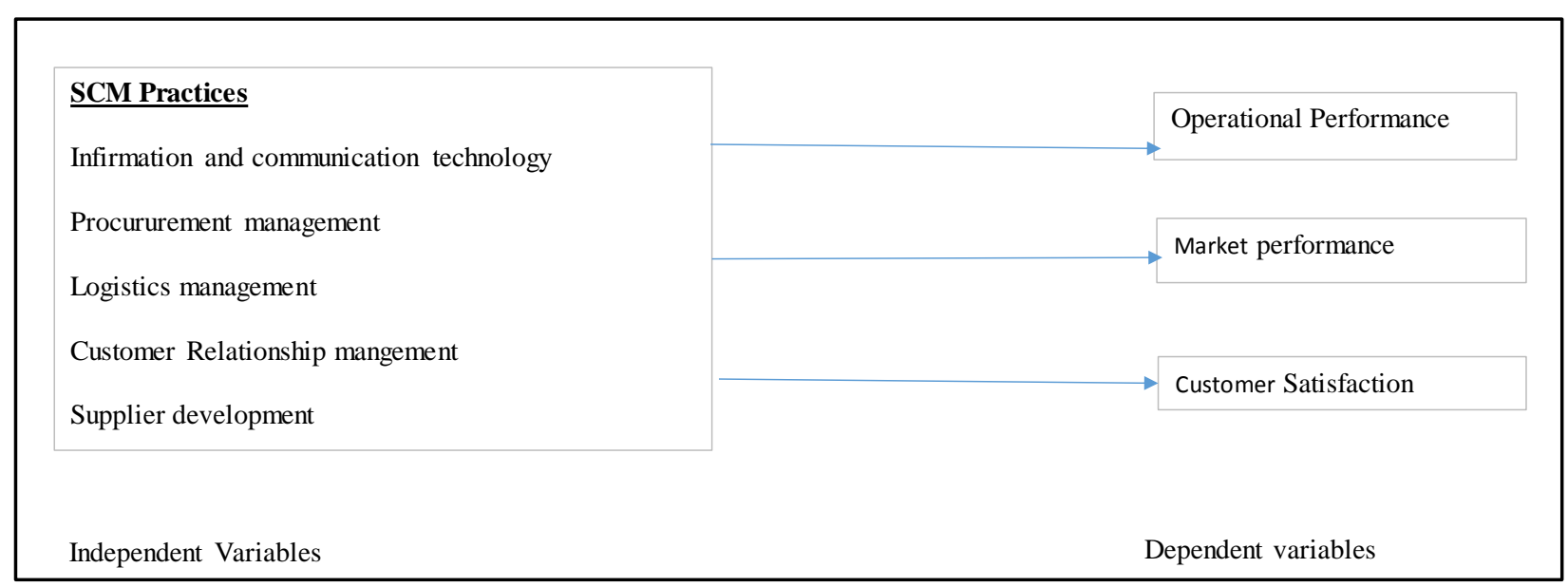

Figure 1: Conceptual Framework

\subsection{Empirical Review}

\subsubsection{SCM Practices}

SCM practices are viewed from a variety of different perspectives and multi-dimensional concept (Sundram, Ibrahim, \& Govindaraju, 2011a). As a result, literature is replete with dimensions of SCMPs from a variety of perspectives but lacks consensus on relevant constructs (Tatoglu et al., 2016). For example, Anatan, (2014), used strategic supplier partnership, customer relationship, level of information sharing, quality of information sharing, and postponement as dimensions of SCMPS. Another study by Spina, Di Serio, Brito, \& Duarte (2015) used Collaboration, demand and supply planning, inventory production and distribution management and logistics as dimensions of SCMPs.

Additionally, Barasa (2016), conceptualized four dimensions of SCM practice, namely green Supply Chain practices, supply chain collaboration practices, Customer Relationship 
Management, and information sharing. Furthermore, Memia (2018) conceptualized Supply chain collaboration Practice, Green Supply chain management Practice, Information Sharing Practice, Customer relationship management Practice. In the same breadth, Apopa (2018) used Supplier selection practices, Supply chain policies, Supplier Collaboration Practices, Risk management practices. Moreover, Chege (2017) used supplier relationship management practices, process management practices, customer relationships management practices and IT support practices.

The existing SCMPs are generic, necessitating the need for more specific practice to the dairy supply chain management. Kumar (2016) conceptualized "Information and Communication Technology Practices, Supplier Relationship Practices, Supply Chain Manufacturing Practices, Inventory management system, Warehousing Management System, Transportation Management System and Customer Relationship Management". While these dimensions of SCM practices are relevant to the dairy industry, their impact on organisational performance has not been empirically tested in the Kenyan context. Thus, the current study proposes Customer relationship management (CRM), information and communication technology (ICT), Logistics Management (LM), Procurement Management (PM) and Supplier Development (SD). The five SCMPs cuts across both sides of the supply chain and internal practices for the focal company.

\subsubsection{Organizational Performance}

Firm performance refers to how well an organization achieves both market-oriented and financial goals (Wong \& Wong, 2011). According to (Arham, 2014), high performing firms can generate a variety of benefits for both the company and society at large such as attracting resources, creating wealth and generating jobs. As a result, literature has identified various measures of organizational performance such as operational, financial and market performance. Scholars, such as Dikshit \& Trivedi, (2012) used parameters like Demand Management, Customer Satisfaction, and Stakeholder Satisfaction as measures of ORGPER. Other measures of ORGPER include responsiveness, flexibility and Quality (R. Kumar \& Mohan, 2014). Another study by Gorane, Prajapati, \& Kant (2018) conceptualized organizational performance in terms of operational customer satisfaction and financial parameters. In summary, ORGPER can be categorized as financial or non-financial metrics. In light of this existing literature, the current study proposes operational, market, and customer satisfaction as the measures of organizational performance.

\subsection{RESEARCH METHODOLOGY}

\subsection{Study design}

The study adopts both descriptive and explanatory research design using both quantitative and qualitative approaches to address to study objectives. The study population comprised of dairy co-operatives operating in the thirteen major milk-producing counties in Kenya. A sample of 109 dairy co-operatives was purposively selected from a population of 150, where the unit manager represented each of them as the survey respondent. Primary data was collected using a crossed ended questionnaire in cross-sectional survey design. After the field survey, a total of 100 questionnaires were returned, representing approximately $92 \%$ response rate. However, only 89 out of the 100 questionnaires returned were complete and valid for analysis. 


\subsection{Measures of Variables}

Multiple item scale was developed to measure the dimensions of SCMPs, namely Information and communication technology, Supplier Development, Procurement, Logistic, and customer relationship management. Further, multiple item scale was adopted from past studies to measure the dimensions of ORGPER (Market, Operational and Customer satisfaction). The scale items for SCMPs were measured on 7 points Likert scale ranging from 1 for never to 7 for every time. Similarly, a 7 Likert scale ranging from $1=$ strongly disagree to $7=$ strongly agree was adopted to measure organizational performance.

\subsection{Data Analysis}

The current study settled on PLS-SEM technique as the most appropriate statistical method for analyzing the set objectives. There has been a proliferation in the application of PLS-SEM in a variety of academic disciplines such as international business marketing, human resource management, accounting management, strategic management, tourism, hospitality and agricultural science have applied PLS-SEM (Rasoolimanesh \& Ali, 2018). One of the advantages of PLS-SEM over other VB-SEM techniques is its ability to specify complex inter-relationships between observed and latent variables (Sarstedt \& Cheah, 2019). Secondly, PLS-SEM is a causal predictive approach to SEM that emphasizes prediction in estimating statistical models, while providing causal explanations (Joseph F Hair, Risher, Sarstedt, \& Ringle, 2018). The interplay between explanation and prediction theory provides an understanding of the underlying causes and prediction, as well as a description of the theoretical constructs and the relationships among them (Shmueli et al., 2019). For instance, Sundram et al., (2011), applied PLS-SEM to investigate the impact of various dimensions of SCMPs on the performance of the supply chain in the electronics industry in Malaysia.

\subsection{Model}

There are two ways to operationalize the outer model; reflective or formative. Indicators or manifest variable measured are assumed to be influenced, affected, or caused by the underlying latent variable in a reflective measurement model (Garson, 2016). In contrast, the indicators of a formative latent construct are the cause rather than being caused by the underlying latent construct (Joe F. Hair, Howard, \& Nitzl, 2020). Using the SmartPLS confirmatory tetrad analysis (CTA) algorithm, the current study conceptualized SCMPs and ORGPER constructs as reflective measurement models shown in Figure 3. The results agree with previous SCM studies that conceptualized SCMPs and ORGPER.

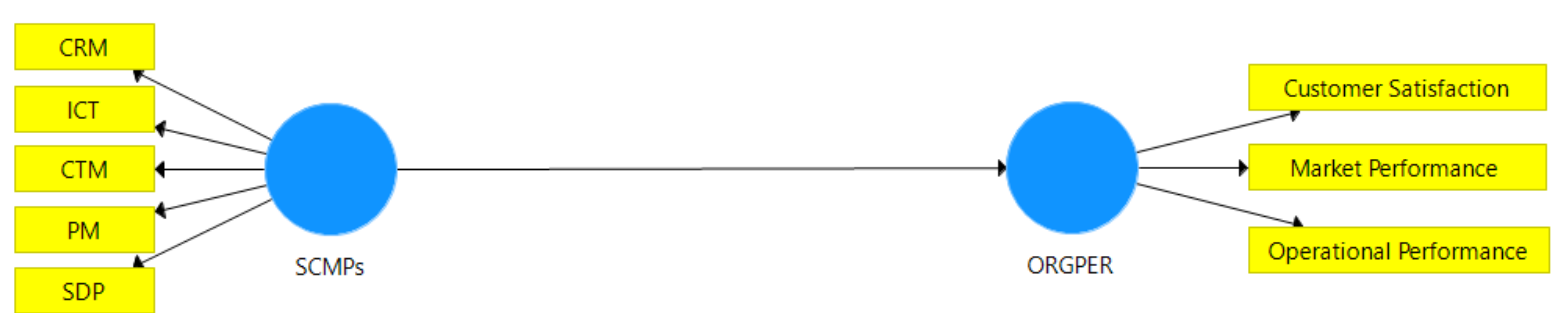

Figure 2: Structural Model 
Table 5, displays the results of regression coefficient $(\beta)$, t-statistic, $p$-values and confidence intervals from SmartPLS bootstrapping algorithm. All the regression coeficients for the paths linking SCMPs $\rightarrow \mathrm{OP}=(\boldsymbol{\beta}=\mathbf{0 . 3 7 1})$, SCMPs $\rightarrow \mathrm{MP}(\boldsymbol{\beta}=\mathbf{0 . 5 5 8})$, SCMPs $\rightarrow$ CUSAT $=(\boldsymbol{\beta}=\mathbf{0 . 5 3 4})$ are stong and positive.

Further results show that the path coefficient for the structural relationship between SCM practices and operational performance $(\beta=0.371)$ is statistically significant at $\mathrm{t}$-Statistic $\geq 1.96(\mathrm{t}$ $=4.520), \mathrm{P}<0.05(\mathrm{P}=0.000)$. Also, the confidence intervals $(0.187,0.507)$ do not include zero leading to the confirmation of hypothesis1.The path coefficient for the structural relationship between SCM practices and market performance is $(\beta=0.558)$ is statistically significant at $t-$ Statistic $\geq 1.96(\mathrm{t}=7.738), \mathrm{P}<0.05(\mathrm{P}=0.000)$. Besides the confidence intervals $(0.396,0.68)$ do not include zero leading to the confirmation of hypothesis2. The path coefficient for the structural relationship between CUSAT is $(\beta=0.534)$ is statistically significant at t-Statistic $\geq$ $1.96(\mathrm{t}=7.282), \mathrm{P}<0.05(\mathrm{P}=0.000)$. Moreover, confidence intervals $(0.366,0.658)$ do not include zero leading to the confirmation of hypothesis3.

Table 5:Test of hypothesis

\begin{tabular}{|c|c|c|c|c|c|c|}
\hline \multirow{2}{*}{ Path } & \multirow{2}{*}{$\begin{array}{l}\text { Path } \\
\text { coeffici } \\
\text { ent }(\beta)\end{array}$} & \multirow{2}{*}{$\begin{array}{l}\text { Standard Deviation } \\
\text { (STDEV) }\end{array}$} & \multirow{2}{*}{$\begin{array}{c}\text { T Statistics } \\
(|\mathrm{O} / \mathrm{STDEV}|)\end{array}$} & \multirow{2}{*}{$\begin{array}{c}\mathbf{P} \\
\text { Valu } \\
\text { es }\end{array}$} & \multicolumn{2}{|c|}{$\begin{array}{l}\text { Confidence } \\
\text { Interval } \\
\end{array}$} \\
\hline & & & & & $2.5 \%$ & $97.5 \%$ \\
\hline $\begin{array}{l}\text { SCMPs -> } \\
\text { OP }\end{array}$ & $0.371 *$ & 0.082 & 4.520 & 0.000 & 0.187 & 0.507 \\
\hline $\begin{array}{l}\text { SCMPs -> } \\
\text { MP }\end{array}$ & $0.558 *$ & 0.072 & 7.738 & 0.000 & 0.396 & 0.68 \\
\hline $\begin{array}{l}\text { SCMPs -> } \\
\text { CUSAT }\end{array}$ & $0.534 *$ & 0.073 & 7.282 & 0.000 & 0.366 & 0.658 \\
\hline
\end{tabular}

Notes $2: * t-S t a t i s t i c ~ \geq 1.96$, two tail at $5 \%$ confidence interval

\subsection{SUMMARY, CONCLUSIONS AND RECOMMENDATIONS}

\section{Summary}

The purpose of this study was to analyze the impact of SCM practices on organizational performance. Specifically, the study sought to explore the influence of SCM practices on customer satisfaction, market and operational performance in the dairy industry in Kenya.

The outer loadings for supplier development, logistics management, purchase management, customer relationship management, information and communication technology shows these dimensions are strong indicators of SCM practices. However, CRM has a relatively low outer loading of 0.663, compared SCMP compared to the other four dimensions. The reason for this is that the implementation of CRM is dependent on a firm's position in the supply chain and hence may not be applicable in all the situations. 
International Journal of Agriculture

ISSN 2520-4629X (Online)

Vol.5, Issue 1, No.2. pp 25 - 38, 2020

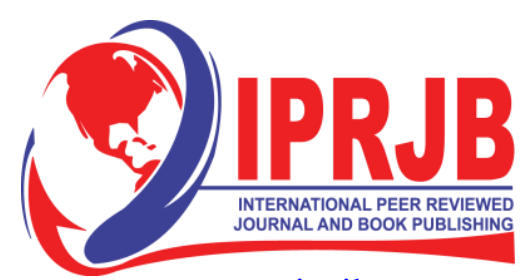

www.iprjb.org

Objective one: SCM practices and operational performance

SCM practices explain $12.8 \%$ of the variance in operational performance, indicating a week model explanatory power. However, the model is still relevant, given its Cross-validated Redundancy $\mathrm{Q}^{2}=0.11$ is greater than zero. Furthermore, the model has a medium effect size measured by Cohen's $\left(\mathrm{f}^{2}=\mathrm{SCMPs}>\mathrm{OP}=0.160\right)$. Besides, bootstrapping results revealed that SCM practices have a positive and statistically significant relationship $(\beta=0.371)$ with operation performance at $5 \%$ significance level in a two-tail test. These results indicate that a unit increase in the standard deviation of SCM practices will increase the standard deviation of operational performance by $37.1 \%$.

\section{Objective two: SCM practices and Market Performance}

SCM practices explain $30.4 \%$ of the variance in market performance, indicating a moderate model explanatory power. Additionally, this model is relevant, given its Cross-validated Redundancy $\mathrm{Q}^{2}=0.270$ is greater than zero. Furthermore, the model has a substantial effect size measured by Cohen's $\left(f^{2}=0.450\right)$. Besides, bootstrapping results revealed that SCM practices have a positive and statistically significant relationship $(\beta=0.558)$ with market performance at $5 \%$. These results indicate that a unit increase in the standard deviation of SCM practices will increase the standard deviation of operational performance by $55.8 \%$.

\section{Objective three: SCM practices and customer satisfaction}

SCM practices explain $27.7 \%$ of the variance in market performance, indicating a moderate model explanatory power. Additionally, this model is relevant, given its Cross-validated Redundancy $\mathrm{Q}^{2}=0.250$ is greater than zero. Furthermore, the model has a substantial effect size measured by Cohen's $\left(f^{2}=0.400\right)$. Besides, bootstrapping results revealed that SCM practices have a positive and statistically significant relationship $(\beta=0.534)$ with customer satisfaction at $5 \%$. These results indicate that a unit increase in the standard deviation of SCM practices will increase the standard deviation of operational performance by $37.1 \%$.

\section{Conclusions}

These findings support the prevailing theory of supply chain management (SCM) as well as previous studies. Barasa (2016) found that SCMPs statistically and significantly predicted the performance of Steel manufacturing companies in Kenya. Another study by Memia (2018) confirmed that contemporary SCM practices have a significant and positive influence on the performance of Large Manufacturing Firms in Kenya. Additionally, Apopa (2018), found a positive association between supply chain management practices and performance of government ministries in Kenya. Furthermore, a study by Chege (2017), established that business value chain practices have a positive and significant effect on the supply chain performance of large manufacturing firms in Kenya.

Thus, SCM practices explain and predict organizational performance in the dairy industry in Kenya. As such, an increase in the level of SCM practices raises the level of organizational performance in the dairy industry in Kenya. Supplier development boosts the performance of farmers by lowering the cost of production, increase milk production per cow and improve quality of milk delivered which in turn lowers the cost of raw material and increase capacity utilization of the dairy processing firms. ICT promotes the speedy exchange of information among the partners in the dairy supply chain that enhances long term relationship between the 
trading partners. Logistics management ensures speedy delivery of raw milk from the collection centres to the processing units in the right amount and quality at minimum cost. In turn, this improves the customer satisfaction, operational and market performance of the dairy processing firms. Purchasing management ensures dairy firms secure the right quantities and quality of raw milk, which guarantee maximization capacity utilization of the processing firms. Finally, customer relationship management promotes customer satisfaction which in turn will secure a wider client base and increase market performance.

\section{Recommendations}

The study findings provide insights on performance improvement in the dairy industry to managers, policymakers and academicians. Thus, managers should pay attention to the following SCM practices: Supplier development, logistics management, purchase management, customer relationship management, information and communication technology shows these dimensions are strong indicators of SCM practices. These dimensions of SCM practices have been confirmed as key performance drivers in the dairy industry in Kenya.

The country should promote policies that enhance the use of economies of scale and size while streamlining the delivery of inputs and services to farmers. Additionally, policies should be designed on measures to reduce the cost of milk transportation and processing.

The study contributes to the literature by identifying SCM practices relevant to the dairy industry. Further, the study validates resource-based view theory which stipulates that resources owned and controlled by a firm explains and predicts the organizational performance in a given industry. By conceptualizing SCM practices as intangible and strategic resources helps to the development and advance the theory of SCM.

Future studies should investigate the moderating role of trust and commitment on the relationship between SCM practices organizational performance. Additionally, studies should be conducted to determine the indirect influence of SCM practices on organizational performance. Also, future studies should consider the non-recursive model between SCM practices and organizational performance.

\section{REFERENCES}

Abdulsamad, A., \& Gereffi, G. (2016). Final report East Africa dairy value chains : Firm capabilities, (July 2017), 1-58. https://doi.org/10.13140/RG.2.2.32203.69920

Anatan, L. (2014). Factors Influencing Supply Chain Competitive Advantage and Performance. International Journal of Business and Information, 9(3), 311-334.

Apopa, V. A. (2018). Influence of Supply Chain Management Practices on Performance of Government Ministries in Kenya. Jomo Kenyatta University of Agricultura and technology.

Arham, A. F. (2014). The Relationship Between Leadership Behaviour, Entrepreneurial Orientation and Organisational Performance in Malaysian Small and Medium Enterprises.

Barasa, P. W. (2016). Contributions Of Supply Chain Management Practices On Performance Of Steel Manufacturing Companies In Kenya. Jomo Kenyatta University of Agriculture and Technology.

Chege, P. W. (2017). Influence of Internal Business Value Chain Practices On The Supply Chain 
International Journal of Agriculture

ISSN 2520-4629X (Online)

Vol.5, Issue 1, No.2. pp 25 - 38, 2020

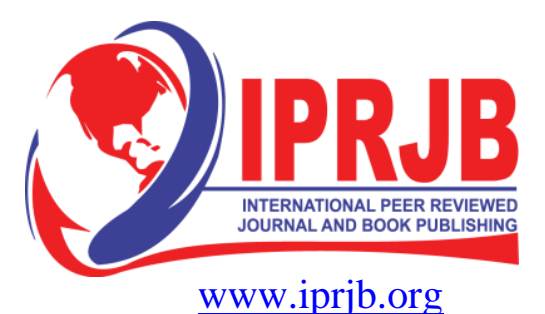

Supply Chain using AHP. Jurnal Teknik Industri, 19(2), 83. https://doi.org/10.9744/jti.19.2.83-92

Muhammad, Z., Akhter, S. N., \& Kafayat Ullah, M. (2014). Dairy Supply Chain Management and Critical an Investigations on Dairy Informal Channel Partners in Pakistan. IOSR Journal of Business and Management, 16(3), 81-87. https://doi.org/10.9790/487x16358187

Mutuerandu, M. N., \& Iravo, D. M. (2014). Impact of Supply Chain Management Practices on Organizational Performance: A Case Study of Haco Industries Limited (Kenya). IOSR Journal of Business and Management, 16(4), 62-64. https://doi.org/10.9790/487X16436264

Rasoolimanesh, S. M., \& Ali, F. (2018). Guest editorial. Journal of Hospitality and Tourism Technology, 9(3), 238-248. https://doi.org/10.1108/JHTT-10-2018-142

Rose, R. C., Abdullah, H., \& Ismad, A. I. (2010). A Review on the Relationship between Organizational Resources, Competitive Advantage and Performance. The Journal of International Social Research, 3(11), 488-498.

Saqib, S., \& Rashid, S. (2013). Resource-Based View of the Firm: The Nature of Resources Required for Competitive. International Journal of Management and Organizational Studies, 2(1), 92-95.

Sarstedt, M., \& Cheah, J. H. (2019). Partial least squares structural equation modelling using SmartPLS: a software review. Journal of Marketing Analytics, 7(3), 196-202. https://doi.org/10.1057/s41270-019-00058-3

Shmueli, G., Sarstedt, M., Hair, J. F., Cheah, J. H., Ting, H., Vaithilingam, S., \& Ringle, C. M. (2019). Predictive model assessment in PLS-SEM: Guidelines for using PLSpredict. European Journal of Marketing, 53(11), 2322-2347. https://doi.org/10.1108/EJM-02-20190189

Spina, D., Di Serio, L., Brito, L., \& Duarte, A. (2015). The Influence of Supply Chain Management Practices in the Enterprise Performance. American Journal of Management, $15(2), 54$.

Sukati, I., Hamid, A. B., Baharun, R., \& Yusoff, R. M. (2012). The Study of Supply Chain Management Strategy and Practices on Supply Chain Performance. Procedia - Social and Behavioral Sciences, 40, 225-233. https://doi.org/10.1016/j.sbspro.2012.03.185

Sundram, V. P. K., Ibrahim, A. R., \& Govindaraju, C. (2011a). Supply chain management practices in the electronics industry in Malaysia Consequences for supply chain performance. An International Journal, 18(6), 834-855. https://doi.org/10.1108/14635771111180725

Sundram, V. P. K., Ibrahim, A. R., \& Govindaraju, V. G. R. C. (2011b). Supply chain management practices in the electronics industry in Malaysia. Benchmarking: An International Journal, 18(6), 834-855. https://doi.org/10.1108/14635771111180725

Susanty, A., Bakhtiar, A., Purwaningsih, R., \& Dewanti, D. F. (2018). Performance measurement of the relationship between farmers-cooperatives-industrial processing milk in 
International Journal of Agriculture

ISSN 2520-4629X (Online)

Vol.5, Issue 1, No.2. pp 25 - 38, 2020

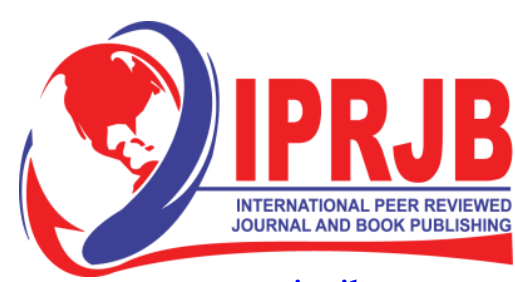

www.iprjb.org

a dairy supply chain: A balanced supply chain management scorecard approach. IEEE International Conference on Industrial Engineering and Engineering Management, 2017Decem, 1387-1391. https://doi.org/10.1109/IEEM.2017.8290120

Tatoglu, E., Bayraktar, E., Golgeci, I., Koh, S. C. L., Demirbag, M., \& Zaim, S. (2016). How do supply chain management and information systems practices influence operational performance? Evidence from emerging country SMEs. International Journal of Logistics

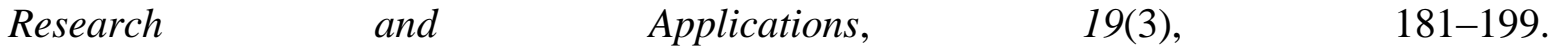
https://doi.org/10.1080/13675567.2015.1065802

Wong, W. P., \& Wong, K. Y. (2011). Supply chain management, knowledge management capability, and their linkages towards firm performance. Business Process Management Journal, 17(6), 940-964. https://doi.org/10.1108/14637151111182701 